\title{
Forest Management Challenges for Sustaining Water Resources in the Anthropocene
}

\author{
Ge Sun ${ }^{1, *}$ and James M. Vose ${ }^{2}$ \\ 1 U.S. Department of Agriculture, Forest Service, Southern Research Station, Eastern Forest Environmental \\ Threat Assessment Center, Raleigh, NC 27606, USA \\ 2 U.S. Department of Agriculture, Forest Service, Southern Research Station, Center for Integrated Forest \\ Science, Department of Forestry and Environmental Resources, Raleigh, NC 27695, USA; jvose@fs.fed.us \\ * Correspondence: gesun@fs.fed.us; Tel.: +1-919-515-9498; Fax: +1-919-513-2978
}

Academic Editor: Timothy A. Martin

Received: 19 January 2016; Accepted: 10 March 2016; Published: 15 March 2016

\begin{abstract}
The Earth has entered the Anthropocene epoch that is dominated by humans who demand unprecedented quantities of goods and services from forests. The science of forest hydrology and watershed management generated during the past century provides a basic understanding of relationships among forests and water and offers management principles that maximize the benefits of forests for people while sustaining watershed ecosystems. However, the rapid pace of changes in climate, disturbance regimes, invasive species, human population growth, and land use expected in the 21st century is likely to create substantial challenges for watershed management that may require new approaches, models, and best management practices. These challenges are likely to be complex and large scale, involving a combination of direct and indirect biophysical watershed responses, as well as socioeconomic impacts and feedbacks. We discuss the complex relationships between forests and water in a rapidly changing environment, examine the trade-offs and conflicts between water and other resources, and propose new management approaches for sustaining water resources in the Anthropocene.
\end{abstract}

Keywords: climate change; disturbance; drought; forest hydrology; modeling; urbanization; watershed management

\section{Introduction}

According to the International Union of Geological Sciences (IUGS), we are officially in the Holocene ("entirely recent") epoch, which began 11,700 years ago after the last major ice age. However, since the 1990s, some scientists have argued that the Earth entered an "Anthropocene" epoch beginning from the industrialization in the 1800s [1,2]. Anthropocene represents anthropo, for "man", and cene, for "new". The Anthropocene epoch is dominated by humans and is characterized by mass extinctions of plant and animal species, water and soil pollution, and an altered atmosphere. We are living in an environment which is significantly different from the Holocene [1,2]. For example, the concentration of atmospheric $\mathrm{CO}_{2}$ during the preindustrial period was $270-275 \mathrm{ppm}$, but it has exceeded $400 \mathrm{ppm}$ today [3]. The world population has reached to 7.3 billion in contrast to merely 1.0 billion in 1800 . The world's urban population (3.9 Billion) has grown more than four times during the past 60 years. Global cropland area expanded from about 4 million $\mathrm{km}^{2}$ in the $1800 \mathrm{~s}$ to 15 million $\mathrm{km}^{2}$ in the $1990 \mathrm{~s}$ at the expense of forest, shrub, and grasslands.

Today about $31 \%$ of the land surface or 4 billion ha is covered by forests [4]. About one half of the primary forests on Earth have disappeared from land conversion, and 16 million hectares of the remaining forests are lost each year. At the same time, forests have been increasingly recognized for their important services, such as water supply and provision of food, medicinal, and forest products, 
as well as other recreational, cultural, aesthetic, and spiritual benefits [5]. For example, on a global scale, forests contribute $\sim 50 \%$ of terrestrial net primary production and store $\sim 45 \%$ of terrestrial carbon [5]. Over half of the water supply in the U.S. flows from forestlands [6,7]. It is estimated that tropical and temperate forests worldwide provide ecosystem goods and services of $\$ 23.32$ trillion per year [8].

Great progress has been made in understanding the complex interactions among forests, water, climate change and humans during the past century (Figure 1). Forest conservation and sustainable forest management practices around the world have slowed forest losses [9]; however, serious future challenges are emerging in the Anthropocene. For example, forest managers face global environmental threats from a warming climate [10,11], and rapid urbanization and demographic changes are increasing the demands of forest ecosystem services such as timber supply, clean water [12], and recreation opportunities. To meet these unprecedented challenges, we propose that land managers will require new thinking and innovative approaches for sustainable forest management in the 21st century [13]. Based on many past successes, there is an expectation by land managers and the public that we have sufficient knowledge and tools to keep watersheds functioning and capable of providing and sustaining ecosystem services into the future [10]. Recent research suggests rapid and substantial progress in our knowledge of watershed sensitivity to rapidly changing conditions $[13,14]$; however, critical knowledge gaps exist in applying forest watershed sciences to sustain ecosystem services in a new environment [10]. In particular, we lack a mechanistic understanding of hydrological responses to the combined effects of climate change (especially climate extremes) and human disturbances such as urbanization and land use change. Without a mechanistic understanding, our modeling tools and management approaches developed in the past may not fit the future environment.

In this communication, we examine how new emerging global environmental threats interact with forest water resources and ecosystem functions in the Anthropocene. We discuss how watershed ecohydrological science [13], the study of interactions between hydrological processes (i.e., water quantity and quantity) and ecological processes (i.e., vegetation dynamics) under a changing environment, can help forest managers achieve forest sustainability for the benefits of current and future generations.

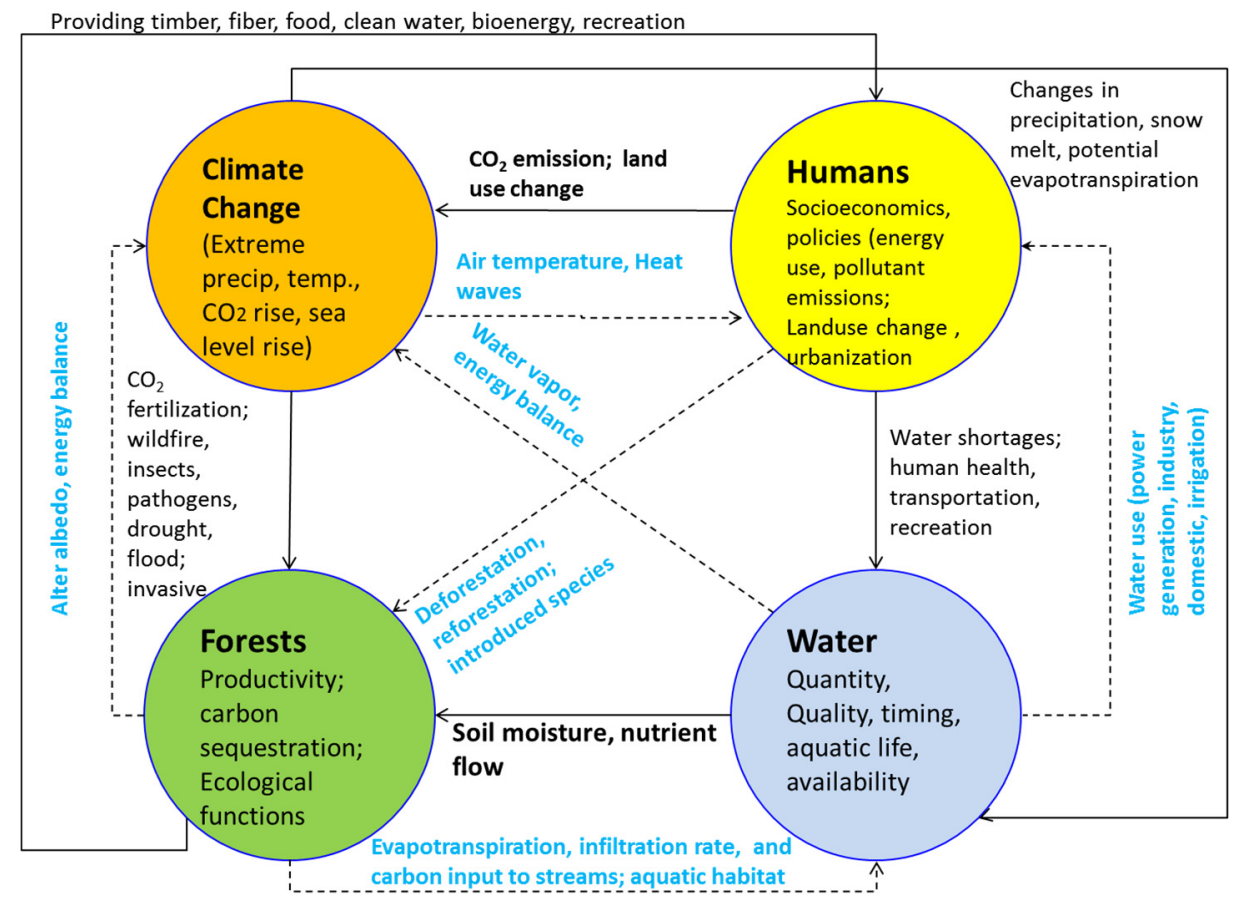

Figure 1. Complex interactions among forests, water resources, climate change, and humans in the Anthropocene. The solid lines represent impacts of stressors while the dotted lines represent feedbacks. 


\section{Emerging Global Environmental Threats to Forest Water Resources}

\subsection{Climate Change: Warming Temperature, Increasing Storms, and Sea Level Rise}

Anthropogenic climate change refers to the changes of meteorological variables such as air temperature and precipitation over an extended period in terms of their average and/or variability. Elevated concentrations of atmospheric carbon dioxide $\left(\mathrm{CO}_{2}\right)$ concentrations and other greenhouse gases are the causes of climate change [3,15]. Since 1750, atmospheric concentrations of $\mathrm{CO}_{2}$ have increased by about $40 \%$, nitrous oxide by $20 \%$, and methane by about $150 \%$. The global average temperatures increased by $0.85{ }^{\circ} \mathrm{C}$ (about $1.6^{\circ} \mathrm{F}$ ) between 1880 and 2012 [15]. Annual precipitation has increased over the mid-latitude terrestrial areas of the Northern Hemisphere at a rate from 1.44 to $3.82 \mathrm{~mm}$ per decade. While annual precipitation trends over other areas have been less significant, the temporal variability of precipitation has increased. Increased ocean temperatures along with the melting of glaciers and ice caps have contributed to an observed rise in global sea level of approximately $0.2 \mathrm{~m}$ between 1901 and 2010 [15].

Climate change is hydrological change, thus it has direct and indirect impacts on forest ecosystems [16] through altering the amount and timing of water and energy movement and availability $[13,17,18]$. One of the most observable changes is hydrologic intensification: the increased frequency of hydrologic extremes such as low and high flows. For example, studies have detected both decreasing and increasing flows in the southern U.S. and the changes were attributed, at least in part, to greater precipitation variability [19]. While changes in annual mean (or totals) values in metrics such as streamflow and groundwater recharge are important, a greater challenge is posed by changes in hydrologic extremes. Climate change implies that the stationarity of ecosystem functions is a false assumption. The lack of stationarity amplifies the challenges because our reference points for developing and applying management responses may no longer be appropriate. The past no longer serves as an appropriate analog for the future and this non-stationarity is likely to amplify in the future. Many of the tools (e.g., models), guidelines, and best management practices have been developed based on historical (and soon to be obsolete) hydrologic conditions and disturbance regimes. A key question is whether existing approaches and tools for protecting and enhancing water resources will be sufficient to mitigate or adapt to future conditions.

\subsection{Population Growth, Urbanization, Land Use Change, and Demographic Change}

Population growth is a strong driver of urbanization, land use change, and water supply stress. By 2050, the world population is projected to be 9.6 billion [20] and majority of the total population is expected to live in urban areas. For example, $80 \%$ of the population lives in urban areas in the United States and urban population has exceeded 50\% in China. In 1950 there were fewer than a dozen Mega (population >10 million) cities worldwide. Today, there were almost 40 Mega Cities (population $>10$ million) [21].

Population expansion over the next century is expected to occur primarily in less-developed regions placing more pressure on forest ecosystems to provide essential ecosystem services. By 2025 it is projected that there will be 50 Mega Cities with the fastest growth occurring in Africa and Asia. Urban expansion is usually characterized as increasing impervious surface areas and losing agricultural and forest lands bring many well-recognized environmental consequences such as water shortages [21,22], water and air pollution [23], and urban heat island [24]. In particular, urbanization affects watershed microclimate, surface water dynamics, groundwater recharge, stream geomorphology, biogeochemistry, and stream ecology [23,25]. We lack knowledge of the impacts of urbanization on ecosystem structure and function, society, and culture under future climate change [22] and how forest management can play a role in an urbanizing world to reduce the negative aspects of urbanization [26].

Securing adequate and reliable water resources for large cities has become one of top priorities for policy makers, city planners, and land managers worldwide [27]. Forested watersheds are often the most important sources of clean water for city inhabitants. As noted previously, there is an 
expectation that we have sufficient knowledge and tools to keep watersheds functioning and capable of providing and sustaining ecosystem services into the future [21]. While substantial progress has been made in research approaches and our understanding of watershed sensitivity to rapidly changing environmental conditions [28], it is largely unknown whether this new knowledge will be sufficient or effective in changing management practices because linking this new knowledge to existing modeling tools, Best Management Practices (BMPs), and guidelines is not straightforward and often requires challenging existing dogma and revising long-standing approaches [29].

\section{Challenges to Forest Water Management}

\subsection{Rapid and Complex Environmental Changes Are Difficult to Understand}

The Anthropocene represents a relatively recent period in the earth's history where human-caused changes are dramatically altering the structure and functions of natural and social systems [1]. Over the past few decades, these changes have accelerated and are expected to accelerate even more rapidly in the future [1]. Changes in the earth's climate have significant impacts on forest water resources by altering the ecohydrological processes [30] such as plant growth rate and water use efficiency and consequently water balances [28]. Direct effects include the influences of altered precipitation amount, timing, and variation, and changes in temperature and elevated atmospheric $\mathrm{CO}_{2}$ concentration [31,32]. Indirect effects include vegetation responses to these direct changes and other disturbances and stressors, such as fire, insect outbreaks, tree mortality [33,34] and sea level rise that are indirectly altered by direct effects. These changes are complex and often occur in combination. An even greater challenge will be new combinations and interactions that we have not observed. Changing conditions may favor (or tolerate) new invasive species that may increase wildfire risk and/or permanently alter hydrologic processes. For example, wetter conditions, fire suppression, and the maturation of much of the forest following widespread harvests during the 20th century in the southern U.S. have resulting in forest "mesophication", a process of shifting species dominance to more xeric conditions. Mesophication caused an increase in evapotranspiration and an decrease in water yield [19].

It is difficult to predict how forest ecosystems will respond to traditional forest management practices in a novel environment. For example, fertilization under drought may do harm to plantation forests and increase vulnerability to drought $[35,36]$. The traditional practices of ditching to grow trees in coastal lowlands may need to be revisited under sea level rise to maximize economic and ecological benefits of intensively managed plantation forests [37,38]. At the large watershed scale, climate change impacts may be masked by management effects. For example, deforestation (deforestation) generally increases (decreases) streamflow, but the influences of this management practice could be offset by increasing or decreasing precipitation and greater evapotranspiration due to climate warming $[39,40]$.

\subsection{Extreme Events Challenge Existing Modeling Tools}

Sophisticated simulation models have been widely used in forest ecohydrological research and watershed management since the 1990s when personal computers became available [41-44]. However, the ability to predict the impacts of extreme events presents considerable challenges to existing models [45]. Performance of watershed-scale models, lumped models in particular, is often evaluated on data that have been averaged in space and time [41] and this precludes evaluation of performance of extreme events [46-48] such as drought and flooding events. Where finer resolution evaluations have been conducted, model performance of most hydrologic models is often poor, especially for drought conditions. The impacts of high rainfall events on streamflow are easier to model because once soils are saturated, hydrologic responses are driven primarily by physical features of the watershed. If these characteristics are well defined, then flood characteristics (amount, timing, location, etc.) can be predicted with relative certainty. However, in mountainous terrain, large storms may increase landslide risk and understanding and modeling the biophysical controls on landslide risk in space and time are difficult [49]. 
Predicting the impacts of drought on streamflow is especially challenging for a variety of reasons. First, there is often a temporal disconnect between meteorological drought and hydrologic drought that varies based on physical properties (e.g., soil depth, soil water holding capacity, topography, etc.) [50,51]. Secondly, physical responses interact with chemical and biological responses [52]. For example, recent warming trends and more prolonged and frequent droughts have increased wildfire frequency and intensity in the western U.S. [53]. Wildfire events can have short term (e.g., peakflow, flooding, landslide) and long term (e.g., geomorphology, land cover shift) consequences to watershed hydrology [54,55]. Droughts have also accelerated the spread and intensity of insect (i.e., Mountain Pine Beetles) attacks and tree die-off [56] in the western U.S. that kill canopy trees, altering stand structure, changing the energy balance of the land surface and affecting many hydrologic processes [57-59]. Consequently, predicting the future impacts of climate warming and hydrologic drought on watershed hydrology is difficult. While there is growing information about how drought interacts with hydraulic architecture and stomatal responses [60-62], we know very little (and hence, can't model) about how drought impacts root structure and function. Furthermore, in mixed species stands drought does not affect trees equally. Some tree species may be more or less affected by drought through better resistance to drought relative to other species, or through enhanced competitive ability during or after drought (i.e., resilience) [63].

Hydrologic models will need to be able to account for these interactions and responses at the species-level. This expectation requires models that couple leaf-level physiology, above- and belowground whole-tree responses, root dynamics and soil water access, stand level responses, and physical hydrology [64]. Generalized empirical models will have limited utility, as conditions are likely to exceed the data used to develop empirical relationships and non-linearity should be expected $[65,66]$. Unfortunately, process-based models require a large amount of parameters and input variables and can be only applied at intensively studied research sites, and thus have limited use to answer regional questions [44].

\subsection{Challenges to Existing Best Management Practices (BMPs) and Modeling Tools}

Extreme climates, such as drought, ice storms, heat waves, are often large scale (i.e., region, continental, global) environmental stressors [67], but their impacts are observable at a range of spatial scales (i.e., tree, stand, basin). In contrast, management responses are typically focused on a limited area, especially in areas with mixed ownership, and usually at the stand scale. For example, climate change, movement of invasive species, water withdrawals, wildfires are global or regional in scale, and cross ecosystem and geographic and political boundaries. Dealing with these large scale issues requires management responses that are also large scale [10]. However, coordinated and large scale management activities are rare. This is especially true where private land is predominant and coordination is especially difficult. Forest BMPs must be designed site specific to suit local watershed physical conditions such as topography, geology and soils, drainage patterns, but they also should consider future climate and hydrologic conditions [29].

Many of models available are not capable of providing the information needed to assist water managers [68]. For example, water managers need information on streamflow amount and quality at a weekly resolution at a spatial scale specific to the water intake or storage reservoir for the water treatment facility. However, models are usually generic and need specific parameters for a certain watershed with unique characteristics and management conditions. Watershed managers also need to know how changing landscape conditions, forest type, and climate interact to determine risks and vulnerabilities, and evaluate management actions to offset them. Hence, models and tools need to be dynamic and account for varying land uses, species and structure [69], and disturbances at fine spatial (e.g., tree) and temporal (e.g., storm event) scales. Empirical rainfall-runoff models built from historical data may not be applicable under future climate change conditions when plant growing season length, forest structure and species composition, and plant water use efficiency [70] have changed over time. 
The ability of current models to provide this type of information is extremely limited and the models do not match the needs of water managers in space and time.

\section{What Is Needed to Meet the Challenges of Increasing Demand for Forest Water Resources?}

\subsection{Anticipate and Manage for Extreme Stressors}

As discussed in the above section, anticipating and managing for extreme stressors poses a great challenge for land managers [71] due to high uncertainty and the lack of effective tools to manage forests at the appropriate scales. Recent mega-droughts, heat waves, and large wildfires portend a future with large-scale changes to ecohydrologic processes and forest functions [72]. In some cases, management activities such as thinning and tree species conversion can increase resilience to these extreme events [11], but increasing resistance on a small subset of stands may be futile unless management occurs at the scale and intensity that will be required. Recognizing that extreme events will alter forests ecosystems, land managers may need to consider management actions that can help facilitate transitions to new and perhaps novel conditions.

\subsection{Develop Flexible Modeling Tools in Anticipating Novel Conditions}

Modeling tools must be able to account for complexity at the correct spatial and temporal scales [73] and they must include variables required to evaluate management options such as fertilization [74], prescribed burning, and thinning [75]. We should also expect that watershed ecosystems will continue to respond to global change in complex ways characterized as nonlinear and threshold response, some of which may be novel and unprecedented. For example, climate warming may increase evaporation potential but the rise of atmospheric $\mathrm{CO}_{2}$ concentration may increase water use efficiency thus reduce water use by trees at the leaf level for some species [76]. The end results on hydrology and ecosystem dynamics at the scale of a watershed with mixed land use and variable precipitation patterns can be unpredictable [31]. As these changes occur, it is uncertain whether existing models will be capable of predicting hydrologic responses at the appropriate spatial and temporal resolution. This is especially true for empirical models, as many of the changes will likely be outside the range of data used to generate relationships. Hydrologic "process-based models" usually also include a high level of empirical simplifications and calibrations that will also challenge the performance of existing models.

Forest ecosystem functions and forest uses by people are changing in Anthropocene. Land managers require new tools to detect change using updated knowledge and adjust management approaches accordingly. The rapid pace of change will amplify the need to detect ecosystem responses over wide spatial scales in both natural and managed forests. Significant advances in remote sensing-based change recognition [77] and tracking system holds promise for monitoring some forest conditions in near real time (i.e., ForWarn) [78]; however, it is unclear if this technology will be appropriate for quantifying and analyzing the effectiveness of management actions. Hence, a combination of remote sensing and "on-the-ground" management platforms such as FIA [79], NEON, and other large-scale networks will be critical for change detection. In addition, new knowledge needs to be rapidly incorporated into management actions and user friendly predictive models, such as the Water Supply Stress Index (WaSSI) model (http:/ /www.wassiweb.sgcp.ncsu.edu/), a water and carbon accounting model that has been used to project climate change impacts on water and carbon resources across the United States $[7,12,80]$. Climate change mitigation and adaptation management guides such as the Template for Assessing Climate Change Impacts and Management Options (TACCIMO) (www.forestthreats.org/taccimo) provide rapid updates to the "state-of-the-science" from the published literature thus connects forest planning to peer-reviewed climate change science; Such a system delivers information from peer-reviewed publication findings describing effects and management options and interactive maps of climate projections and models that provide insight into climate influences on natural resources. Additional information could be provided from land 
managers as they observe changes in the forests that they manage. New approaches to collecting and disseminating information such as citizen science networks and "crowd sourcing" approaches could accelerate the pace of experiential knowledge, observations, and data collection to supplement information from the published literature. Finally, improvements in data collection, storage, and access systems over the past few decades has created massive amounts of readily available data that has facilitated large scale "big data" analyses of hydrologic trends [81]. These new approaches are likely to provide significant insight into the interactions between large scale drivers such as climate change, and smaller scale controls such as land use and management intensity. We also recommend that models be available as open source that can be modified as new data and understanding become available.

\subsection{Be Realistic about Forest Management Options}

Active management including implementing Best Management Practices (BMPs) is critical to offset increasing environmental threats to forest ecosystem services [82]. In the past, improvement in forest condition with forest management in many parts of the world has been tremendously successful [9]. Among the best examples, is the recovery of heavily cutover lands in the eastern U.S. Reforestation and the implementation of best management practices has restored these forests and associated ecosystem services $[82,83]$. Forest coverage in China has been increasing thanks to large scale reforestation campaigns that aims at reducing soil erosion and protecting remaining forests in the last three decades [84]. The socioeconomic (i.e., poverty reduction through food subsidies through the Grain for Green Project) and ecological benefits (i.e., soil erosion control, carbon sequestration) of these policy-driven ecological restoration efforts are well documented [85]. However, tradeoffs of ecosystem services of reforestation and unintended environmental consequences such as decline in deep soil moisture (i.e., soil desiccation) and water yield reduction in some arid regions $[86,87]$ are emerging.

Can we manage forests in the face of future threats to continue to provide the level of existing ecosystem services? Or, more importantly, can we provide and sustain ecosystem services required in the future? We contend that large scale and extreme changes in social-economic and biophysical conditions will preclude the ability to sustain many ecosystem services. We contend that it will be difficult to "manage" our way out of future threats due to the large uncertainty of environmental conditions. Traditional approaches to forest conservation and management that assume a constant climate; stable forest dynamics, and socioeconomic, and demographic conditions; and rely heavily on historical reference conditions will be inadequate [88] to meet future demand on forest ecosystem services. Instead, new approaches that focus on anticipating and guiding ecological responses to change, are urgently needed to ensure the full value of forest ecosystem services for future generations. For example, warmer and drier conditions are increasing the frequency and size of wildfires throughout many areas of the world [89]. How to manage the threats from large area of wildfires is debatable although comprehensive strategies have been proposed [90-92]. There are proposed management options that may be implemented to minimize the impacts of drought on water quantity and quality [10]. For example, reducing leaf area by thinning and regenerating cut or planting native tree species that use less water than exotic species may help reduce water stress and increase water availability to tree growth [93], aquatic systems in forest streams, and downstream water supply for people. However, as with other natural disturbances, droughts are difficult to prepare for because they are unpredictable. Management actions such as thinning [75] and prescribed burning [94] are typically not implemented at a scale or intensity to offset climatic driving forces. Similarly, the growing conflict between managing for carbon $v$ s. managing for water [95] will only increase as efforts to mitigate $\mathrm{CO}_{2}$ emissions using bioenergy promote management of fast growing species [96,97]. In short, managers should prepare for growing conflicts among management priorities and the need to articulate the limitations of forest management for providing ecosystem services in the future. The disparity between winners and losers will widen, and trade-offs will need to be carefully evaluated. 


\section{Summary}

In the remainder of the twenty-first century, humans will likely be impacted by the degradation of ecosystem services, and the potential loss of the planet's ability to recover [98]. The forestry community is facing large global environmental and socioeconomic challenges, such as climate change and urbanization, to meet the ever increasing demand for ecosystem services from forest ecosystems. Traditional watershed management is facing new challenges as rapid and compounded environmental, economic, and social change contribute to an increasingly uncertain future [19]. Our knowledge of ecohydrological response to extreme stressors (e.g., drought) is lacking, so current modeling tools may be insufficient to project the impacts of climate change on ecosystem functions at the scales needed in forest management. Future forest water resource management must consider the trade-offs of forest ecosystem services and coupled nature-human systems. Existing forest Best Management Practices (BMPs) [82] should be revisited to mitigate and adapt to the negative impacts of natural and anthropogenic disturbances that are expected to increase in the Anthropocene.

Conflicts of Interest: The authors declare no conflict of interest.

\section{References}

1. Steffen, W.; Grinevald, J.; Crutzen, P.; McNeill, J. The Anthropocene: Conceptual and historical perspectives. Philos. Trans. R. Soc. A 2011, 369, 842-867. [CrossRef]

2. Steffen, W.; Crutzen, P.J.; McNeill, J.R. The Anthropocene: Are humans now overwhelming the great forces of nature. Ambio 2007, 36, 614-621. [CrossRef]

3. IPCC. Summary for policymakers. In Climate Change 2014: Impacts, Adaptation, and Vulnerability. Part A: Global and Sectoral Aspects; Contribution of Working Group ii to the Fifth Assessment Report of the Intergovernmental Panel on Climate Change; Field, C.B., Barros, V.R., Dokken, D.J., Mach, K.J., Mastrandrea, M.D., Bilir, T.E., Chatterjee, M., Ebi, K.L., Estrada, Y.O., Genova, R.C., et al, Eds.; Cambridge University Press: Cambridge, UK; New York, NY, USA, 2014; p. 32.

4. FAO. Global Forest Resources Assessment 2015: How Have the World's Forests Changed?; FAO: Rome, Italy, 2015.

5. Bonan, G.B. Forests and climate change: Forcings, feedbacks, and the climate benefits of forests. Science 2008, 320, 1444-1449. [CrossRef] [PubMed]

6. Brown, T.C.; Hobbins, M.T.; Ramirez, J.A. Spatial distribution of water supply in the coterminous United States. J. Am. Water Resour. Assoc. 2008, 44, 1474-1487. [CrossRef]

7. Sun, G.; Caldwell, P.; Noormets, A.; McNulty, S.G.; Cohen, E.; Myers, J.M.; Domec, J.C.; Treasure, E.; Mu, Q.Z.; Xiao, J.F.; et al. Upscaling key ecosystem functions across the conterminous United States by a water-centric ecosystem model. J. Geophys. Res. Biogeosci. 2011, 116. [CrossRef]

8. De Groot, R.; Brander, L.; van der Ploeg, S.; Costanza, R.; Bernard, F.; Braat, L.; Christie, M.; Crossman, N.; Ghermandi, A.; Hein, L.; et al. Global estimates of the value of ecosystems and their services in monetary units. Ecosyst. Serv. 2012, 1, 50-61. [CrossRef]

9. MacDicken, K.G. Global forest resources assessment 2015: What, why and how? For. Ecol. Manag. 2015, 352, 3-8. [CrossRef]

10. Vose, J.M.; Klepzig, K.D. Climate Change Adaptation and Mitigation Management Options: A Guide for Natural Resource Managers in Southern Forest Ecosystems; CRC Press: Boca Raton, FL, USA, 2014; p. 476.

11. Ford, C.R.; Laseter, S.H.; Swank, W.T.; Vose, J.M. Can forest management be used to sustain water-based ecosystem services in the face of climate change? Ecol. Appl. 2011, 21, 2049-2067. [CrossRef] [PubMed]

12. Sun, G.; McNulty, S.G.; Myers, J.A.M.; Cohen, E.C. Impacts of multiple stresses on water demand and supply across the southeastern United States. J. Am. Water Resour. Assoc. 2008, 44, 1441-1457. [CrossRef]

13. Vose, J.M.; Sun, G.; Ford, C.R.; Bredemeier, M.; Otsuki, K.; Wei, X.H.; Zhang, Z.Q.; Zhang, L. Forest ecohydrological research in the 21st century: What are the critical needs? Ecohydrology 2011, 4, 146-158. [CrossRef]

14. Vogel, R.M.; Lall, U.; Cai, X.M.; Rajagopalan, B.; Weiskel, P.K.; Hooper, R.P.; Matalas, N.C. Hydrology: The interdisciplinary science of water. Water. Resour. Res. 2015, 51, 4409-4430. [CrossRef] 
15. Stocker, B.D.; Roth, R.; Joos, F.; Spahni, R.; Steinacher, M.; Zaehle, S.; Bouwman, L.; Xu-Ri; Prentice, I.C. Multiple greenhouse-gas feedbacks from the land biosphere under future climate change scenarios. Nat. Clim. Chang. 2013, 3, 666-672. [CrossRef]

16. Melillo, J.M.; Richmond, T.; Yohe, G.W. Climate Change Impacts in the United States: The Third National Climate Assessment; Global Change Research Program: Washington, DC, USA, 2014.

17. Felzer, B.; Sahagian, D. Climate impacts on regional ecosystem services in the United States from cmip3-based multimodel comparisons. Clim. Res. 2014, 61, 133-155. [CrossRef]

18. Sun, S.L.; Sun, G.; Caldwell, P.; McNulty, S.; Cohen, E.; Xiao, J.F.; Zhang, Y. Drought impacts on ecosystem functions of the us national forests and grasslands: Part ii assessment results and management implications. For. Ecol. Manag. 2015, 353, 269-279. [CrossRef]

19. Vose, J.M.; Martin, K.L.; Barten, P.K. Applications of forest hydrologic science to watershed management in the 21st century. In Forest Hydrology; Amatya, T., Williams, L., de Jong, C., Eds.; CABI: Cambridge, UK, in press.

20. UN. World Urbanization Prospects; the 2014 Revision; UN: New York, NY, USA, 2014.

21. Li, E.J.; Endter-Wada, J.; Li, S.J. Characterizing and contextualizing the water challenges of megacities. J. Am. Water. Resour. Assoc. 2015, 51, 589-613. [CrossRef]

22. McDonald, R.I.; Green, P.; Balk, D.; Fekete, B.M.; Revenga, C.; Todd, M.; Montgomery, M. Urban growth, climate change, and freshwater availability. Proc. Natl. Acad. Sci. USA 2011, 108, 6312-6317. [CrossRef] [PubMed]

23. O’Driscoll, M.; Clinton, S.; Jefferson, A.; Manda, A.; McMillan, S. Urbanization effects on watershed hydrology and in-stream processes in the southern United States. Water-Sui 2010, 2, 605-648. [CrossRef]

24. Zhou, D.C.; Zhao, S.Q.; Zhang, L.X.; Sun, G.; Liu, Y.Q. The footprint of urban heat island effect in China. Sci. Rep. 2015, 5. [CrossRef] [PubMed]

25. Paul, M.J.; Meyer, J.L. Streams in the urban landscape. Annu. Rev. Ecol. Syst. 2001, 32, 333-365. [CrossRef]

26. Sun, G.; Lockaby, B.G. Water quantity and quality at the urban-rural interface. Urban Rural Interfaces Link. People Nat. 2012, 29-48.

27. Sun, G.; Michelsen, A.M.; Sheng, Z.P.; Fang, A.F.; Shang, Y.Z.; Zhang, H.L. Featured collection introduction: Water for megacities challenges and solutions. J. Am. Water Resour. Assoc. 2015, 51, 585-588. [CrossRef]

28. Vose, J.M.; Miniat, C.F.; Luce, C.H.; Asbjornsen, H.; Caldwell, P.V.; Campbell, J.L.; Grant, G.E.; Isaak, D.J.; Loheide, S.P.L., II; Sun, G. Ecohydrological implications of drought for forests in the United States. For. Ecol. Manag. 2016, in press.

29. Marion, D.A.; Sun, G.; Caldwell, P.V.; Miniat, C.F.; Ouyang, Y.; Amatya, D.M.; Clinton, B.D.; Conrads, P.A.; Gull Laird, S.; Dai, Z.; et al. Managing forest water quantity and quality under climate change. In Climate Change Adaption and Mitigation Management Optionsa Guide for Natural Resource Managers in Southern Forest Ecosystems; Vose, J.M., Klepzig, K.D., Eds.; CRC Press/Taylor and Francis: Boca Raton, FL, USA, 2014; pp. 249-306, p. 58.

30. Parolari, A.J.; Katul, G.G.; Porporato, A. An ecohydrological perspective on drought-induced forest mortality. J. Geophys. Res. Biogeosci. 2014, 119, 965-981. [CrossRef]

31. Tor-Ngern, P.; Oren, R.; Ward, E.J.; Palmroth, S.; McCarthy, H.R.; Domec, J.C. Increases in atmosphericco(2) have little influence on transpiration of a temperate forest canopy. New Phytol. 2015, 205, 518-525. [CrossRef] [PubMed]

32. Hanson, P.J.; Wullschleger, S.D.; Norby, R.J.; Tschaplinski, T.J.; Gunderson, C.A. Importance of changing $\mathrm{CO}_{2}$, temperature, precipitation, and ozone on carbon and water cycles of an upland-oak forest: Incorporating experimental results into model simulations. Glob. Chang. Biol. 2005, 11, 1402-1423. [CrossRef]

33. Allen, C.D.; Breshears, D.D.; McDowell, N.G. On underestimation of global vulnerability to tree mortality and forest die-off from hotter drought in the anthropocene. Ecosphere 2015, 6, 1-55. [CrossRef]

34. Allen, C.D.; Macalady, A.K.; Chenchouni, H.; Bachelet, D.; McDowell, N.; Vennetier, M.; Kitzberger, T.; Rigling, A.; Breshears, D.D.; Hogg, E.H.; et al. A global overview of drought and heat-induced tree mortality reveals emerging climate change risks for forests. For. Ecol. Manag. 2010, 259, 660-684. [CrossRef]

35. Ward, E.J.; Domec, J.C.; Laviner, M.A.; Fox, T.R.; Sun, G.; McNulty, S.; King, J.; Noormets, A. Fertilization intensifies drought stress: Water use and stomatal conductance of pinus taeda in a midrotation fertilization and throughfall reduction experiment. For. Ecol. Manag. 2015, 355, 72-82. [CrossRef] 
36. Bartkowiak, S.M.; Samuelson, L.J.; McGuire, M.A.; Teskey, R.O. Fertilization increases sensitivity of canopy stomatal conductance and transpiration to throughfall reduction in an 8-year-old loblolly pine plantation. For. Ecol. Manag. 2015, 354, 87-96. [CrossRef]

37. Lohmus, A.; Remm, L.; Rannap, R. Just a ditch in forest? Reconsidering draining in the context of sustainable forest management. Bioscience 2015, 65, 1066-1076. [CrossRef]

38. Amatya, D.M.; Gregory, J.D.; Skaggs, R.W. Effects of controlled drainage on storm event hydrology in a loblolly pine plantation. J. Am. Water Resour. Assoc. 2000, 36, 175-190. [CrossRef]

39. Wei, X.H.; Liu, W.F.; Zhou, P.C. Quantifying the relative contributions of forest change and climatic variability to hydrology in large watersheds: A critical review of research methods. Water-Sui 2013, 5, 728-746. [CrossRef]

40. Liu, W.F.; Wei, X.H.; Liu, S.R.; Liu, Y.Q.; Fan, H.B.; Zhang, M.F.; Yin, J.M.; Zhan, M.J. How do climate and forest changes affect long-term streamflow dynamics? A case study in the upper reach of poyang river basin. Ecohydrology 2015, 8, 46-57. [CrossRef]

41. Sun, S.L.; Sun, G.; Caldwell, P.; McNulty, S.G.; Cohen, E.; Xiao, J.F.; Zhang, Y. Drought impacts on ecosystem functions of the us national forests and grasslands: Part i evaluation of a water and carbon balance model. For. Ecol. Manag. 2015, 353, 260-268. [CrossRef]

42. Tian, S.Y.; Youssef, M.A.; Sun, G.; Chescheir, G.M.; Noormets, A.; Amatya, D.M.; Skaggs, R.W.; King, J.S.; McNulty, S.; Gavazzi, M.; et al. Testing drainmod-forest for predicting evapotranspiration in a mid-rotation pine plantation. For. Ecol. Manag. 2015, 355, 37-47. [CrossRef]

43. Sun, G.; Riekerk, H.; Comerford, N.B. Modeling the hydrologic impacts of forest harvesting on florida flatwoods. J. Am. Water Resour. Assoc. 1998, 34, 843-854. [CrossRef]

44. Ollinger, S.V.; Aber, J.D.; Federer, C.A. Estimating regional forest productivity and water yield using an ecosystem model linked to a gis. Landsc. Ecol. 1998, 13, 323-334. [CrossRef]

45. Amatya, D.M.; Sun, G.; Rossi, C.G.; Ssegane, H.S.; Nettles, J.E.; Panda, S. Forests, land use change, and water. In Impact of Climate Change on Water Resources in Agriculture; Rodrigues, R., Ed.; CRC Press/Taylor \& Francis Group: Boca Raton, FL, USA, 2015.

46. Sun, S.L.; Chen, H.S.; Ju, W.M.; Yu, M.; Hua, W.J.; Yin, Y. On the attribution of the changing hydrological cycle in poyang lake basin, China. J. Hydrol. 2014, 514, 214-225. [CrossRef]

47. Hao, L.; Zhang, X.Y.; Gao, J.M. Simulating human-induced changes of water resources in the upper xiliaohe river basin, China. Environ. Eng. Manag. J. 2011, 10, 787-792.

48. Hao, L.; Sun, G.; Liu, Y.Q.; Qian, H. Integrated modeling of water supply and demand under management options and climate change scenarios in Chifeng city, China. J. Am. Water Resour. Assoc. 2015, 51, 655-671. [CrossRef]

49. Band, L.E.; Hwang, T.; Hales, T.C.; Vose, J.; Ford, C. Ecosystem processes at the watershed scale: Mapping and modeling ecohydrological controls of landslides. Geomorphology 2012, 137, 159-167. [CrossRef]

50. Geris, J.; Tetzlaff, D.; McDonnell, J.; Soulsby, C. The relative role of soil type and tree cover on water storage and transmission in northern headwater catchments. Hydrol. Process. 2015, 29, 1844-1860. [CrossRef]

51. Adams, H.R.; Barnard, H.R.; Loomis, A.K. Topography alters tree growth-climate relationships in a semi-arid forested catchment. Ecosphere 2014, 5, 1-16. [CrossRef]

52. Hanson, P.J.; Amthor, J.S.; Wullschleger, S.D.; Wilson, K.B.; Grant, R.F.; Hartley, A.; Hui, D.; Hunt, E.R.; Johnson, D.W.; Kimball, J.S.; et al. Oak forest carbon and water simulations: Model intercomparisons and evaluations against independent data. Ecol. Monogr. 2004, 74, 443-489. [CrossRef]

53. Flannigan, M.D.; Krawchuk, M.A.; de Groot, W.J.; Wotton, B.M.; Gowman, L.M. Implications of changing climate for global wildland fire. Int. J. Wildland Fire 2009, 18, 483-507. [CrossRef]

54. Bladon, K.D.; Emelko, M.B.; Silins, U.; Stone, M. Wildfire and the future of water supply. Environ. Sci. Technol. 2014, 48, 8936-8943. [CrossRef] [PubMed]

55. Ice, G.G.; Neary, D.G.; Adams, P.W. Effects of wildfire on soils and watershed processes. J. For. 2004, 102, 16-20.

56. Adams, H.D.; Luce, C.H.; Breshears, D.D.; Allen, C.D.; Weiler, M.; Hale, V.C.; Smith, A.M.S.; Huxman, T.E. Ecohydrological consequences of drought- and infestation-triggered tree die-off: Insights and hypotheses. Ecohydrology 2012, 5, 145-159. [CrossRef] 
57. Bearup, L.A.; Maxwell, R.M.; Clow, D.; McCray, J.E. Hydrological effects of forest transpiration loss in bark beetle-impacted watersheds. Nat. Clim. Chang. 2014, 4, 481-486. [CrossRef]

58. Langhammer, J.; Su, Y.; Bernsteinova, J. Runoff response to climate warming and forest disturbance in a mid-mountain basin. Water-Sui 2015, 7, 3320-3342. [CrossRef]

59. Pugh, E.; Gordon, E. A conceptual model of water yield effects from beetle-induced tree death in snow-dominated lodgepole pine forests. Hydrol. Process. 2013, 27, 2048-2060. [CrossRef]

60. Domec, J.C.; Noormets, A.; King, J.S.; Sun, G.; McNulty, S.G.; Gavazzi, M.J.; Boggs, J.L.; Treasure, E.A. Decoupling the influence of leaf and root hydraulic conductances on stomatal conductance and its sensitivity to vapour pressure deficit as soil dries in a drained loblolly pine plantation. Plant Cell Environ. 2009, 32, 980-991. [CrossRef] [PubMed]

61. Noormets, A.; McNulty, S.G.; DeForest, J.L.; Sun, G.; Li, Q.; Chen, J. Drought during canopy development has lasting effect on annual carbon balance in a deciduous temperate forest. New Phytol. 2008, 179, 818-828. [CrossRef] [PubMed]

62. Domec, J.C.; Palmroth, S.; Ward, E.; Maier, C.A.; Therezien, M.; Oren, R. Acclimation of leaf hydraulic conductance and stomatal conductance of pinus taeda (loblolly pine) to long-term growth in elevated $\mathrm{CO}_{2}$ (free-air $\mathrm{CO}_{2}$ enrichment) and n-fertilization. Plant Cell Environ. 2009, 32, 1500-1512. [CrossRef] [PubMed]

63. Ford, C.R.; Hubbard, R.M.; Vose, J.M. Quantifying structural and physiological controls on variation in canopy transpiration among planted pine and hardwood species in the southern appalachians. Ecohydrology 2011, 4, 183-195. [CrossRef]

64. Tague, C.L.; McDowell, N.G.; Allen, C.D. An integrated model of environmental effects on growth, carbohydrate balance, and mortality of pinus ponderosa forests in the southern rocky mountains. PLoS ONE 2013, 8, e80286. [CrossRef] [PubMed]

65. Zhou, G.; Wei, X.; Chen, X.; Zhou, P.; Liu, X.; Xiao, Y.; Sun, G.; Scott, D.F.; Zhou, S.; Han, L.; et al. Global pattern for the effect of climate and land cover on water yield. Nat. Commun. 2015, 6. [CrossRef] [PubMed]

66. Sun, G.; Alstad, K.; Chen, J.Q.; Chen, S.P.; Ford, C.R.; Lin, G.H.; Liu, C.F.; Lu, N.; McNulty, S.G.; Miao, H.X.; et al. A general predictive model for estimating monthly ecosystem evapotranspiration. Ecohydrology 2011, 4, 245-255. [CrossRef]

67. Sun, G.; Caldwell, P.V.; McNulty, S.G.; Georgakakos, A.P.; Arumugam, S.; Cruise, J.; McNider, R.T.; Terando, A.; Conrads, P.A.; Feldt, J.; et al. Impacts of climate change and variability on water resources in the southeast USA. In Climate of the Southeast United States: Variability, Change, Impacts, and Vulnerability, NCA Southeast Technical Report; Ingram, K.T., Dow, K., Carter, L., Anderson, J., Eds.; Island Press: Washington, DC, USA, 2013; p. 31.

68. Amatya, D.M.; Douglas-Mankin, K.R.; Williams, T.M.; Skaggs, R.W.; Nettles, J.E. Advances in forest hydrology: Challenges and opportunities. Trans. ASABE 2011, 54, 2049-2056. [CrossRef]

69. Brantley, S.T.; Miniat, C.F.; Elliott, K.J.; Laseter, S.H.; Vose, J.M. Changes to southern appalachian water yield and stormflow after loss of a foundation species. Ecohydrology 2015, 8, 518-528. [CrossRef]

70. Liu, Y.B.; Xiao, J.F.; Ju, W.M.; Zhou, Y.L.; Wang, S.Q.; Wu, X.C. Water use efficiency of China's terrestrial ecosystems and responses to drought. Sci. Rep. 2015, 5. [CrossRef]

71. Patel-Weynand, T.; Peterson, D.L.; Vose, J.M. Effects of Climatic Variability and Change on Forest Ecosystems: A Comprehensive Science Synthesis for the U.S.; USDA Forest Service Pacific Northwest Research Station: Portland, OR, USA, 2012; p. 265.

72. Matyas, C.; Sun, G. Forests in a water limited world under climate change. Environ. Res. Lett. $2014,9$. [CrossRef]

73. Porporato, A.; Feng, X.; Manzoni, S.; Mau, Y.; Parolari, A.J.; Vico, G. Ecohydrological modeling in agroecosystems: Examples and challenges. Water. Resour. Res. 2015, 51, 5081-5099. [CrossRef]

74. Amatya, D.M.; Rossi, C.G.; Saleh, A.; Dai, Z.; Youssef, M.A.; Williams, R.G.; Bosch, D.D.; Chescheir, G.M.; Sun, G.; Skaggs, R.W.; et al. Review of nitrogen fate models applicable to forest landscapes in the southern US. Trans. ASABE 2013, 56, 1731-1757.

75. Sun, G.; Caldwell, P.V.; McNulty, S.G. Modelling the potential role of forest thinning in maintaining water supplies under a changing climate across the conterminous United States. Hydrol. Process. 2015. [CrossRef] 
76. Cheng, L.; Zhang, L.; Wang, Y.P.; Yu, Q.; Eamus, D.; O'Grady, A. Impacts of elevated $\mathrm{CO}_{2}$, climate change and their interactions on water budgets in four different catchments in Australia. J. Hydrol. 2014, 519, 1350-1361. [CrossRef]

77. Hansen, M.C.; Potapov, P.V.; Moore, R.; Hancher, M.; Turubanova, S.A.; Tyukavina, A.; Thau, D.; Stehman, S.V.; Goetz, S.J.; Loveland, T.R.; et al. High-resolution global maps of 21st-century forest cover change. Science 2013, 342, 850-853. [CrossRef] [PubMed]

78. Norman, S.P. Highlights of Satellite-Based Forest Change Recognition and Tracking Using the Forwarn System; U.S. Department of Agriculture, Forest Service, Research \& Development, Southern Research Station: Asheville, NC, USA, 2013; p. 30.

79. Coulston, J.W.; Wear, D.N.; Vose, J.M. Complex forest dynamics indicate potential for slowing carbon accumulation in the southeastern United States. Sci. Rep. 2015, 5. [CrossRef] [PubMed]

80. Caldwell, P.V.; Sun, G.; McNulty, S.G.; Cohen, E.C.; Myers, J.A.M. Impacts of impervious cover, water withdrawals, and climate change on river flows in the conterminous US. Hydrol. Earth Syst. Sci. 2012, 16, 2839-2857. [CrossRef]

81. Rice, J.S.; Emanuel, R.E.; Vose, J.M.; Nelson, S.A.C. Continental U.S. Streamflow trends from 1940 to 2009 and their relationships with watershed spatial characteristics. Water Resour. Res. 2015, 51, 6262-6275. [CrossRef]

82. Cristan, R.; Aust, W.M.; Bolding, M.C.; Barrett, S.M.; Munsell, J.F.; Schilling, E. Effectiveness of forestry best management practices in the United States: Literature review. For. Ecol. Manag. 2016, 360, 133-151. [CrossRef]

83. Boggs, J.; Sun, G.; McNUlty, S.G. Effects of timber harvest on water quantity and quality in small watersheds in the piedmont of North Carolina. J. For. 2015, 114, 27-40. [CrossRef]

84. Sun, G.; Zhou, G.Y.; Zhang, Z.Q.; Wei, X.H.; McNulty, S.G.; Vose, J.M. Potential water yield reduction due to forestation across China. J. Hydrol. 2006, 328, 548-558. [CrossRef]

85. Lu, Y.H.; Fu, B.J.; Feng, X.M.; Zeng, Y.; Liu, Y.; Chang, R.Y.; Sun, G.; Wu, B.F. A policy-driven large scale ecological restoration: Quantifying ecosystem services changes in the loess plateau of China. PLoS ONE 2012, 7, e31782. [CrossRef] [PubMed]

86. Cao, S.X.; Sun, G.; Zhang, Z.Q.; Chen, L.D.; Feng, Q.; Fu, B.J.; McNulty, S.; Shankman, D.; Tang, J.W.; Wang, Y.H.; et al. Greening China naturally. Ambio 2011, 40, 828-831. [CrossRef] [PubMed]

87. Liang, W.; Bai, D.; Wang, F.Y.; Fu, B.J.; Yan, J.P.; Wang, S.; Yang, Y.T.; Long, D.; Feng, M.Q. Quantifying the impacts of climate change and ecological restoration on streamflow changes based on a budyko hydrological model in China's Loess Plateau. Water Resour. Res. 2015, 51, 6500-6519. [CrossRef]

88. Golladay, S.W.; Martin, K.L.; Vose, J.M.; Wear, D.N.; Covich, A.P.; Hobbs, R.J.; Klepzig, K.D.; Likens, G.E.; Naiman, R.J.; Shearer, A.W. Achievable future conditions as a framework for guiding forest conservation and management. For. Ecol. Manag. 2016, 360, 80-96. [CrossRef]

89. Liu, Y.Q.; Stanturf, J.; Goodrick, S. Trends in global wildfire potential in a changing climate. For. Ecol. Manag. 2010, 259, 685-697. [CrossRef]

90. Moritz, M.A.; Batllori, E.; Bradstock, R.A.; Gill, A.M.; Handmer, J.; Hessburg, P.F.; Leonard, J.; McCaffrey, S.; Odion, D.C.; Schoennagel, T.; et al. Learning to coexist with wildfire. Nature 2014, 515, 58-66. [CrossRef] [PubMed]

91. Stephens, S.L.; Agee, J.K.; Fule, P.Z.; North, M.P.; Romme, W.H.; Swetnam, T.W.; Turner, M.G. Managing forests and fire in changing climates. Science 2013, 342, 41-42. [CrossRef] [PubMed]

92. North, M.P.; Stephens, S.L.; Collins, B.M.; Agee, J.K.; Aplet, G.; Franklin, J.F.; Fule, P.Z. Reform forest fire management. Science 2015, 349, 1280-1281. [CrossRef] [PubMed]

93. Grant, G.E.; Tague, C.L.; Allen, C.D. Watering the forest for the trees: An emerging priority for managing water in forest landscapes. Front. Ecol. Environ. 2013, 11, 314-321. [CrossRef]

94. Vose, J.M.; Elliott, K.J. Oak, fire, and global change: What might the future hold? Fire Ecol. 2016. in prerss.

95. Jackson, R.B.; Jobbagy, E.G.; Avissar, R.; Roy, S.B.; Barrett, D.J.; Cook, C.W.; Farley, K.A.; le Maitre, D.C.; McCarl, B.A.; Murray, B.C. Trading water for carbon with biological sequestration. Science 2005, 310, 1944-1947. [CrossRef] [PubMed]

96. King, J.S.; Ceulemans, R.; Albaugh, J.M.; Dillen, S.Y.; Domec, J.C.; Fichot, R.; Fischer, M.; Leggett, Z.; Sucre, E.; Trnka, M.; et al. The challenge of lignocellulosic bioenergy in a water-limited world. Bioscience 2013, 63, $102-117$. 
97. Vose, J.M.; Miniat, C.F.; Sun, G.; Caldwell, P.V. Potential implications for expansion of freeze-tolerant eucalyptus plantations on water resources in the southern United States. For. Sci. 2015, 61, 509-521. [CrossRef]

98. Steffen, W.; Persson, A.; Deutsch, L.; Zalasiewicz, J.; Williams, M.; Richardson, K.; Crumley, C.; Crutzen, P.; Folke, C.; Gordon, L.; et al. The anthropocene: From global change to planetary stewardship. Ambio 2011, 40, 739-761. [CrossRef] [PubMed]

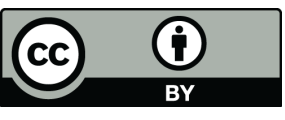

(C) 2016 by the authors; licensee MDPI, Basel, Switzerland. This article is an open access article distributed under the terms and conditions of the Creative Commons by Attribution (CC-BY) license (http://creativecommons.org/licenses/by/4.0/). 